\title{
Consumer Protection for Accessing Essential Needs in Disaster Situation in Indonesia
}

\author{
Ahmad Zuhairi* \\ Faculty of Law \\ University of Mataram \\ Mataram, Indonesia \\ ahmadzuhairi@unram.ac.id
}

\author{
Khairus Febryan F \\ Faculty of Law \\ University of Mataram \\ Mataram, Indonesia \\ khairusfebryan@unram.ac.id
}

\author{
Dwi Martini \\ Faculty of Law \\ University of Mataram \\ Mataram, Indonesia \\ dwimaret@unram.ac.id
}

\author{
Ari Rahmad Hakim BF \\ Faculty of Law \\ University of Mataram, \\ Mataram, Indonesia \\ arirahmadhakim17@gmail.com
}

\author{
Diangsa Wagian \\ Faculty of Law \\ University of Mataram, \\ Mataram, Indonesia \\ dwagian@yahoo.com
}

\begin{abstract}
In event of disaster, essential needs are purposed to support human life but in the business practices, the case is often the opposite. Suddenly the price of essential needs increases dramatically. Business actors often take advantage of this condition to increase the price of essential needs so that it can threaten human survival. This research aims to find out consumer protection in accessing essential needs in the event of disaster in Indonesia. The research employed normative legal research using statute and conceptual approach. This study revealed no stipulated regulation that explicitly concerns consumer protection in accessing essential needs in the event of a disaster; however, several laws stipulate the prohibition of accumulation of goods. Many business actors utilize this vacuum of the norm to increase the price of essential needs in the event of a disaster. The condition threatens consumers' sustainability in maintaining their lives because many consumers who cannot access essential needs will be in a vulnerable condition. Therefore, to protect consumer needs to construct new law that states prohibition to increase the price of essential needs up to maximum price in disaster.
\end{abstract}

\section{Keywords: Consumer Protection, Essential Needs, Disaster}

\section{INTRODUCTION}

Consumer protection is an international issue, including in Indonesia. This is due to increased global trade impacted by the consumer. Along with the growth of the world of trade and industry, the consumer's position, specifically in developing countries, is increasingly deteriorating due to weak bargaining power, education and ignorance of goods and services circulating in the market. Therefore, the growth of the world of trade and industry, on the one hand, always demands serious effort to protect the interest of consumers in the order it can create fair trade or commerce for consumers.[1]

One of the most critical consumer rights is the right to safety and comfort to goods bought or needed. In addition, the rights regulated in Consumer Protection Law are the right to choose in goods and service following the exchange rate and conditions and the promised guarantee.[2]

The principle of business actors is how to get profit as much as possible with the small capital, but the principle can bring consumer as a victim. That is why Consumer
Protection Law and Act. Number 5 of 1999 concerning the Prohibition of Monopolistic Practice and Unfair Business Competition is one package regulation where the government can intervene in the market that can protect consumers.

Unlike capitalism theory proponent by Adam Smith, if the supply more and the demand less, the price will rise and vice versa when the price falls. That is the law of the market; it can run by itself without intervention from the government. Nevertheless, the natural and human condition is not always standard, when the disaster condition, specifically in Indonesia, often shows that essential needs are needed not cheaper but more expensive due to distribution scarcity of goods. Therefore, the market law is implemented as usual. One example of this was when the great earthquake disaster in 2018 in Lombok Island, when the society recovered and built their house, but the cement price was high enough in that condition.

In recent year, the World infected pandemic Corona Virus (Covid-19), including Indonesia. When this case has started to unsettle the public, to mitigate the spread of coronavirus, people were asked to wear masks. So that immediately masks become an essential need, not only for medical workers but also for the communities. However, in reality, amid a tense situation regarding the spread of the coronavirus, the price of masks was unreasonable, wherein normal conditions were only Rp. 35,000., - but when disaster strikes, the price even in online shopping was Rp. 850,000., [3]. Of course, the spirit to control the market with two laws, namely the anti-monopoly law and the consumer protection law, must be used.

The significance of this research is that besides consumer protection law, two laws that regulate consumer protection in accessing essential needs in a disaster situation are food law and trade, but the laws still have weaknesses. They only regulate the prohibition of business actors in hoarding essential needs by communities, affecting price volatility in the amount of time, specifically in three months.[4] However, in a disaster situation, many business actors take advantage of the situation to make a high profit, without hoarding the goods, but they sell essential needs at a high price in a disaster situation, such as cement after the earthquake in 2018 in Lombok Island and mask in pandemic 
Covid-19 which happen at the beginning of 2020. In that situation, many people cannot access the essential needs to protect and maintain their life because of the bad habit of business actors, and no regulation can intervene in the actions. Therefore, this research is significant as an input to regulate consumer protection in accessing essential needs in disaster situations.

\section{METHODS}

The method of this research is normative (doctrinal) legal research with descriptive-analytical research specifications. Descriptive analytical research aims to illustrate, examine, and explain the problem to be studied and consumer protection in accessing essential needs in disaster conditions. The approach used in this research is the statutory approach and conceptual approach. The statute approach is carried out by examining all laws and regulations relating to the legal issues being addressed. The conceptual approach moves from the views and doctrines that develop in the science of law. This study includes a literature study, so this research emphasizes secondary data relevant to the topic being raised. The design of the study of literature studies is a series of activities to obtain secondary data such as primary, secondary, and tertiary legal materials through literature study as a data collection technique, which is then read, recorded and analyzed qualitatively to obtain actual conclusions.

\section{RESULTS AND DISCUSSION}

\section{A. Consumer protection in modern society}

Generally, discussion on consumer protection was started in western countries such as Europe and the United States. In the field of law, this is a relatively new object. In the Netherland, for example, consumer protection is considered a legal matter since thirty years ago.[5]

Meanwhile, in the United States, the consumer protection scheme had started in 1962. The first person who sounded the importance of consumer protection was President John F Kennedy; in his speech in front of the congress, he mentioned consumer's influential position in societyreflected that 2/3 (two-third) of the total amount of money used daily is generated from the consumer. Even though their voice usually unheard. The consumer often unprotected and therefore affected by unqualified goods or service.

Legal protection on the consumer was encouraged by the massive and complex industry development as it is necessary to prevent adverse effects that may harm people who consume industrial products. Usually, consumers' losses are related to product quality, unfair competition, forgery, fraud, and misleading advertisement, which caused material loss and may cause death.

In 1985, this issue started to get more intense attention worldwide. The UN general assembly stated, "consumer resolution" (resolution 39/248) on April 9, 1985. [6]. This resolution protected several aspects of consumer's interests, namely :

1. Consumer protection on health risk and safety.

2. Promotion and protection of the economic interests of the consumer.
3. The availability of adequate information to enable them to choose products freely

4. The availability of an adequate compensation mechanism.

5. Freedom to form consumer organization and the opportunity to speak their opinion since the decision-making process related to consumers' interests.

The economic law and improved procurement system project (ELIPS) stated that the fast and complex development of the industry, which also becomes more competitive, leads to consumer protection. It proposed nine legal formulation materials on consumer protection, namely:

1. Un-equal bargaining power;

2. Freedom of contract versus fairness of contract;

3. The requirement to provide information for the consumer including public announcement law and financial announcement law;

4. Regulations regarding business actor's behaviour/ action including misleading directions and shrewdness in trade;

5. Regulations regarding product's quality including product's guarantee and safety;

6. Access to credit (report, credit, nondiscrimination);

7. Limitation to the right to terminate guarantee period;

8. Regulations on pricing;

9. Correction.

The power of the consumer protection movement showed up through the establishment of the International consumer protection organization. This organization is known as the International Organization of Consumer Union. It has earned adequate power as it also has stated 15 May as the world's consumer rights day.

In Indonesia, consumer protection started in 1997, at the beginning of the economic crisis. The importance of consumer protection for industrial society such as in Indonesia has been sounded since 1980 by Mudjono. He mentioned it in his speech at the symposium on consumer protection aspects in Jakarta. The pressure to set forth consumer protection law arises with establishing antimonopoly and business competition law that was formed to fulfil the loan requirement asked by the International Monetary Fund (IMF), which was used to overcome the monetary crisis.

Prior to Law Number 8 of 1999, consumer protection was based on old and colonial legal products such as:

1. Book of Civil law (KUH Perdita), book of trade law (KUHD). Even though the "consumer" term is not found in these laws, it mentioned related terms such as "buyer", "lender", "insured" or "passenger" which did not define them as final or in-between users.

2. Law number 10 of 1961 concerning the enactment of government's regulation as replacement of law number 1 of 1961 concerning goods. This 
establishment aimed to own and regulate traded goods in Indonesia.

3. The government's regulation number 9 of 1964 concerning Industrial Standard was an implementation of law number 10 of 1961. One of the standard industrial aims is to increase the industry's quality and product.

4. The industrial minister's decree No 81/M/SK/2/1974 concerning the legalization of analysis method standard and material quality qualifications and industrial products.

It is considering the background of consumer protection law that seems to be so sudden and unwell prepared, no wonder that there are some missing points of an appropriate consumer legal protection. Hence, several offences conducted by business actors are unable to solve by the government. Take the powder milk case or Dewi Prieta Mulyasari or cellphone credit withholding as examples that make consumer protection seem powerless.

\section{B. Consumer Protection in Law No. 8 of 1999 concerning Consumer Protection.}

Generally, legal protection for the consumer has regulated clearly in Law No. 8 of 1999 concerning Consumer Protection. In Article 4, point (a) of the law stated that: Consumer rights are rights to conformity, security and safety in consuming goods and or services. In addition, In the Consumer Protection Law Article 7 has regulated the obligation of business actors for preventing of business actors conducted an action that cause harm to consumers, which stated that: The obligations of the entrepreneurs: (a) to act in good faith in conducting the business; (b) to provide correct, transparent end honest information with regard to the condition and warranty of the goods and/or services and provide explanation on the use, repair and maintenance; (c) to treat and serve the consumers honestly and adequately and non-discriminatively; (d) to guarantee the goods and/or services produced and/or traded based on the prevailing quality standard provisions of the goods and/or services; (e) to provide the opportunity to the consumers to test and or/try on certain goods and/or services and provide warranty and/or guarantee on the produced and/or traded goods; (f) to provide compensation, redress and/or substitution for the damages caused by the use, consumption and application of the goods and/or services; ( $g$ ) to provide compensation, redress and/or substitution if the goods and/or services received or used, do not accord with the agreement. [7]

\section{Prohibition of Hoarding Essential Needs}

Specifically, two laws in Indonesia prohibit and can protect the consumer in fulfilling essential needs in a crucial situation. First of all, is Law No. 7 of 2014 concerning Trade (hereinafter referred to as the Trade Law) contains a provision that protects consumers to access essential goods related to survival in emergency circumstances such as scarcity of good or disaster. This is stipulated in Article 29 paragraph (1) Business actors are prohibited from storing goods basic needs and/or essential goods in a certain amount of time and in the event of scarcity of goods, price volatility, and/or traffic barriers for Trade in Goods.
The elucidation of Article 25 paragraph (1) of the Trade Law stipulates that the essential goods are goods that are related to the survival of the significant number of people with a large scale of the fulfilment of the needs and become a supporting factor for the community welfare, such as rice, sugar, cooking oil, butter, beef, chicken, eggs, milk, corn, soybeans, and iodized salt. Furthermore, what is meant by essential goods are strategic items that play an essential role in determining the smoothness of national development, such as fertilizer, cement, fuel oil and gas. Meanwhile, an adequate amount of necessities and /or essential goods needed by the community is available throughout the territory of the Unitary State of the Republic of Indonesia.

Business actors who store staples and/or essential goods in a certain amount of time and the event of scarcity of goods, price volatility, and/or traffic barriers for Trade in Goods referred to in Article 29 paragraph (1) shall be punished with imprisonment of 5 (five) years and/or a fine of up Rp50.000.000.000,00 (fifty billion rupiahs).

To deal with the problem of uncontrolled price and to provide consumer protection for essential goods, the Government is given the authority to intervene in the prices of essential goods needed by consumers under certain conditions, as stated in Article 26 Paragraph (1) In certain conditions that can disturb national trade activities, the Government is obliged to ensure the supply and stabilization of prices for necessities and essential goods. (2) Guarantee of supply and price stabilization of necessities and essential goods as referred to in paragraph (1) is carried out to maintain price affordability at the consumer level and protect producers' income. Paragraph (3) In ensuring the supply and price stabilization of staple goods and essential goods, the minister sets prices, manages stocks and logistics, and manages Exports and Imports.

Other than Trade Law, to protect consumers for goods needed in the disaster situation, it is also regulated in Law No. 18 of 2012 concerning Food. In Article 53, Food Business Actors are prohibited from hoarding or storing more than the maximum staple food as regulated in Article 52. In Article 53, consumer protection is only to protect against the hoarding of essential foods. What is meant by food is everything that comes from biological sources of the agricultural, plantation, forestry, fishery, animal husbandry, water and water products, whether processed or not for human consumption, including Food additives, ingredients, Food raw materials, and other materials used in the process of preparing, processing and/or manufacturing Food or beverages.

\section{The weakness of consumer protection law, Trade Law and Food Law in protection to consumer in accessing essential needs in a disaster situation}

Look at the construction of Article 4 point (a) in Consumer Protection Law that the consumer's fundamental rights are rights to security and safety in consuming goods and/or services. However, the right emerged once the transaction is completed. The question is how these rights will be fulfilled if the product is essential to save or maintain health, but suddenly the product is scarce, and the price soared. This situation often happens (business as usual) in the business transaction since business has its own rules, 
namely supply and demand. In addition, article 4 point (g) which regulate business actors to serve appropriately, honestly to consumer and Article 7 from point (a) to point (g) which regulate the obligation of business actors for preventing an action that causes harm to consumers. Nevertheless, in practice, consumers are served, even in disaster situations, at an irrational price, although the goods are essential for sustainable human life. In addition, the articles is too general which cannot be implemented in the field.

Like Trade Law and Food Law, let us take a closer look into the construction of Trade Law in Article 29 paragraph (1), where entrepreneurs are prohibited from storing or hoarding staples and / or essential goods under certain conditions. So, it is apparent in the article that what is prohibited is the accumulation of goods. Meanwhile, if business actors do not accumulate the goods needed in a disaster, but take the opportunity to increase the price dramatically up to $1000 \%$, for example. This is not included in the construction of that article. This means that the business actor does not violate Article 29 paragraph (1).

In addition, to avoid differences in interpretation, the Trade Law has explained necessities: rice, sugar, cooking oil, butter, beef, chicken, eggs, milk, corn, soybeans, iodized salt, as well as other essential items, such as fertilizers, cement, and fuel oil and gas.

It can be seen from the explanation of the article that necessities are still limited. Inevitable disaster requires different necessities. In the case of the Lombok earthquake in 2018, many business actors increased the price of cement at high prices without any restrictions. Besides that, when the Covid-19 pandemic outbreak hit the world, including Indonesia, the price of Masks, which previously cost Rp35.000/box, suddenly soared to the price of Rp850.000/box. Whereas in these conditions, consumers urgently need the items such as masks and other personal protective equipment to prevent the spread of the virus and defend their lives not to be attacked by the Covid-19 pandemic. In addition, masks are not included in necessities and essential items in explaining the Trade Law. This shows the weakness of Article 29 paragraph (1), which only prohibits the accumulation of goods but does not prohibit the prices raised highly and are not affordable.

Law No. 18 of 2012 concerning Food in Article 53, consumer protection is only to protect against the hoarding of Essential Needs. What is meant by food is everything that comes from biological sources of the agricultural, plantation, forestry, fishery, animal husbandry, water and water products, whether processed or not for human consumption, including Food additives, ingredients: food raw materials and other materials used in preparing, processing and manufacturing food or beverages.

In its implementation, the provisions of Article 53 are less effective because, in Article 52 of the Food Law, the Government emphasizes the mechanisms, procedures and the maximum amount of staple food storage by food business actors as stipulated in a Government Regulation. The delegation is further regulated in Article 64, Article 65, and Article 67 of Government Regulation Number 17 of 2015 concerning Food Security and Nutrition, which principally regulates the mechanism, procedures and maximum amount of staple food storage by business actors regulated by a Ministerial Regulation carry out Government affairs in the trade sector. However, until now, the Regulation of the Minister of Trade in question has not been issued, so the implementation of Article 53 in conjunction with Article 133 of the Food Law has not been implemented because the technical regulations governing the violation model in the maximum amount of staple food storage do not exist. So that the amount of hoarding exceeds the maximum amount required is still unclear [4].

\section{E. Consumer protection in a disaster situation}

The three laws protecting consumers mentioned above have a weakness in that they can only regulate business actors who hoard goods but cannot regulate business actors who sell goods needed by people in disaster situation at high prices without hoarding. Several essential needs are prone to be hoard and sold at high prices in a disaster situation, such as regulated in Presidential Regulation Number 71 of 2015 concerning Determination and Storage of Basic Needs and Important Goods

Therefore, learn from several countries that can be adopted in Indonesia, several countries have good protection to consumer in every situation including disaster situation, such as Philippines, Nigeria, and Malaysia. In those countries, Malaysia has the best regulation in consumer protection in a disaster situation. Malaysia has Price Control and Profiteering Act 2011 [8]. The act of hoarding is not explicitly described in the law, but it can be seen that the act of hoarding and then selling goods which price is under control at a high price is a crime in the Price Control and Anti-Profiteering Act 2011 because of the act of hoarding, the perpetrator will have benefit from an unreasonable sales price.

Indonesia can take the lesson to learn from Malaysia, and very urgent to have Price Control and Profiteering Act. It can be explicitly constructed to supervise and punish the business actors who take advantage in disaster situations, although they are not hoarding the essential needs but selling at an unreasonable price, especially in disaster situations. In the offence formulation of Trade Law and Food Law now, there are not found the phrase that prohibits business actors from selling goods that are urgently needed in a disaster situation and for goods needed to mitigate the impact of a disaster, such as a musk in pandemic Covid-19, cement in after earthquake and other essential goods. In addition, The law can be used to guide and intervene the business actors to conduct their business in good faith and protect consumers in crucial situations.

\section{CONCLUSION}

Based on the discussion above, the form of consumer protection to essential needs when a disaster is regulated in Law Number 8 of 1999 concerning Consumer Protection contained about the obligation of business actors to conduct good faith in running their business. In business ethics, good faith requires business actors for-profit orientation and the security, safety, and comfort of consumers. In addition, protection provided to consumers in a disaster situation is regulated by Food Law and Trade Law. Both of the laws prohibited and impose penalties for business actors who 
hoard essential needs in a certain amount and time when there is a shortage of goods and price fluctuation. However, the laws only regulated hoarding of essential needs and essential needs, which cause high price significantly. However, they do not regulate explicitly related to the prohibition for business actors who increase the price dramatically because, in practice, many business actors do not store goods but the increasing outrageous price when consumer safety is threatened. Therefore, Indonesia needs a Price Control and Anti-Profiteering Act for regulating and preventing price rise significantly when a disaster occurs.

\section{ACKNOWLEDGMENT}

Thanks to the faculty of law, Mataram University has a program to support research every year for all lecturers. This research can be conducted because of the support from the program. In addition, we are grateful to collaborate with Strengthening Legal Education in Eastern Indonesia (SLEEI) that also supports this research to be published in proceeding or journal to read this research. We are also grateful to $\mathbf{M}$. Riadhussyah, Anang Alfian, and Metajuridica Team for much help.

\section{REFERENCES}

[1] J. Widijantoro, "Mewujudkan Perniagaan Berkeadilan Melalui Peningkatan Akses Keadilan Konsumen," Mimb. Huk., vol. 28, no. 3, pp. 439-452, 2016.

[2] A. H. Barkatullah, Hukum Perlindungan Konsumen; Kajian Teoritis Dan Perkembangan Pemikiran. 2008.

[3] Ali Akhmad Noor Hidayat, "Harga Masker di Glodok Rp 850 Ribu, Hand Sanitizer Rp 110 Ribu - Bisnis Tempo.co,” Mar. 02, 2020. https://bisnis.tempo.co/read/1314546/harga-masker-diglodok-rp-850-ribu-hand-sanitizer-rp-110-ribu (accessed May 22, 2021).

[4] R. Tulus et.all, "Rekonstruksi Kebijakan Hukum Pidana Dalam Upaya Penanggulanang Tindak Pidana Ekonomi (Studi Kasus Terhadap Tindak Pidana Penimbunan Barang)," Diponegoro Law Rev., vol. 5, no. 2, 2016.

[5] J. Sidabalok, Hukum Perlindungan Konsumen Di Indonesia. Bandung: citra aditya bakti, 2006

[6] A. Sutedi, Tanggung Jawab Produk Dalam Hukum Perlindungan Konsumen. Bogor: Ghalia Indonesia, 2008.

[7] Ahmad Zuhairi, "Konstruksi Perlindungan Hukum Bagi Pengadu/Pelapor Kerugian Konsumen Dari Tuntutan Pencemaran Oleh Pelaku Usaha/Produsen," J. Ius Kaji. Huk. dan Keadilan, vol. 3 , pp. 54-73.

[8] Adeline Wong and Krystal Ng, "MEMBER FIRM OF BAKER \& MCKENZIE INTERNATIONAL Tax Kuala Lumpur One Year in Review: Price Control and Anti-Profiteering Enforcement in Malaysia." Accessed: May 22, 2021. [Online]. Available: www.wongpartners.com. 